\title{
Textaraðirnar og kirkjuárið í sögulegu ljósi ${ }^{1}$
}

\section{Inngangur}

Í hverri guðspjónustu er lesinn ritningartexti úr Gamla testamentinu, bréfum eða öðrum ritum Nýja testamentisins og loks úr einu guðspjallanna. Pessir prír textar mynda eina heild. Deir fjalla um svipað efni og eru bundnir tilteknum helgidögum kirkjuársins. Greinileg innbyrðis tengsl eru líka á milli pessara textablokka, frá sunnudegi til sunnudags, en auk pess er að finna í peim tilvísanir til annarra helgidaga kirkjuársins. Dæmi um slíkt er t.d. boðunardagur Maríu, en hann er níu mánuðum fyrir jól. Ritningartextarnir hafa pví ekki aðeins sjálfstætt vægi innan guðspjónustunnar, heldur má líkja peim við mósaíksteina sem raðað er saman eftir tímalínu kirkjuársins par sem peir birta megindrætti litskrúðugrar myndar hjálpræðissögunnar. Fræðimenn hafa reynt að grafast fyrir um tilurð pessarar textaraðar og hvaða prón búi að baki henni. Hér á eftir verður sú viðleitni lítillega skoðuð. ${ }^{2}$

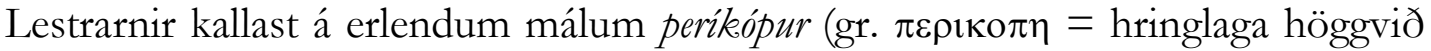
stykki), en pað orð vísar til valins hlutar. Hugtakið kemur fyrst fyrir hjá Jústínusi kirkjuföður og píslarvotti (d. 165), en hann notar pað um ritningarstaði sem trúfræðileg kenning byggist á. Đað er ekki fyrr en á 17. öld sem byrjað er að nota hugtakið períkópur yfir pá texta sem lesnir eru upp í guðspjónustum og á íslensku eru oftast kallaðir textaraðir. ${ }^{3}$ Um upphaf ritningarlesturs í kristnum guðspjónustum er hins vegar margt á huldu, bæði hvað varðar fjölda lestra og hvaða textar voru lesnir.

Rétt er að geta pess að fyrir handbækur skiptir fyrsta textaröð kirkjuársins, hin fornkirkjulega röð, miklu máli. Kafla- og versaskipting sú sem við pekkjum úr Biblíunni kom tiltölulega seint fram á sjónarsviðið. Tildrögin að pví að skipta ritum Biblíunnar niður í tölusetta kafla má rekja til ársins 1205 pegar erkibiskupinn af Kantaraborg, Stefán Langton (1150-1228), innleiddi pá. Heiðurinn af versaskiptingunni á aftur á móti prentari í París að nafni Robertus Stephanus (1503-1559) sem setti hana inn í gríska útgáfu Nýja testamentisins árið 1551, en kerfið var síðan tekið upp og notað á öll rit Biblíunnar. Pegar efni fyrstu textaraðarinnar er skoðað ber að hafa petta í huga. Upphaflega hefur pað verið svo er lesarinn las úr ritningunni að hann ákvað sjálfur hvar hann byrjaði og hvar hann hætti. Snemma var pó farið að setja merki inn í textann sem sögðu til um hvar átti að byrja og hvar að hætta. En peirri aðferð var líka beitt við textalestur innan samkunduhúsanna. ${ }^{4}$

\footnotetext{
Höfundur tileinkar greinina minningu Eberhards Wölfel (1927-2019) og Einars Sigurbjörnssonar (1944-2019). Ég styðst einkum við pýsku fræðimennina Gerhard Kunze, Peter C. Bloth, Karl-Heinrich Bieritz, Karl Dienst og Frieder Schulz.

Karl Dienst, „Perikopen“, RGG 5/1961, bls. 220-224, hér 220.

Gottfried Reeg, „Perikopen“, RGG 6/2003, bls. 1111-1112. Dess má geta að versaskiptingin kom til Íslands með Dorláksbiblíu árið 1644. Sjá: Sigurður Ægisson, Íslenska Biblian: Ágrip rúmlega fjögurra alda sögu, Siglufjörður: Sigurður Ægisson, 2015.
} 


\section{Lestrar og textaröð}

Rýrar heimildir eru til um lestra í guðspjónustum frumsafnaðarins og fornkirkjunnar og pess vegna verða menn að styðjast við misvel ígrundaðar tilgátur um petta tímabil. Flestir fræðimenn eru sammála um að í elstu gerðum textaraða hafi alla jafnan verið lesið úr bréfum Nýja testamentisins og úr einu guðspjallanna. Af elstu heimild um lestra í guðspjónustunni má draga pá ályktun að svipuð aðferð hafi verið notuð og í samkunduhúsum gyðinga. En fræðimenn deila nokkuð um að hve miklu leyti frumsöfnuðurinn og fornkirkjan tileinkuðu sér pessa venju úr gyðingdómi. ${ }^{5}$

Í Nehemíabók er greint frá pví er Esra spámaður stígur upp á háan trépall á torginu í Jerúsalem á nýárshátíð Ísraelsmanna og les úr lögmálinu frá birtingu til hádegis. Greint er frá pví er hebreski textinn var lesinn, útskýrður pá, líklega eins og síðar varð, pýddur yfir á arameísku, „til pess að fólkið skildi pað sem lesið var“ (Neh 8.112, sbr. 5Mós 31.10-13). Af pessu má draga pá ályktun að pegar á fjórðu öld f.Kr. hafi verið vani að lesa úr textum ritningarinnar í musterinu og henni hafi fylgt pýðing og prédikun. Fundist hafa textaraðir sem notaðar voru í samkunduhúsum. Um er að ræða tvær hefðir, annars vegar eins árs ferli sem á rætur að rekja til textaraðar sem gyðinglegir fræðimenn, sem störfuðu í Babýlon og Palestínu um 250-500 e.Kr., tóku saman. Í henni er gert ráð fyrir pví að lögmálið eða Mósebækurnar séu fluttar yfir árið í 54 lestrum. Fyrsta Mósebók er lesin í 12 lestrum, Önnur Mósebók 1́ 11, Driðja Mósebók í 10 lestrum, Fjórða Mósebók í 10 og Fimmta Mósebók í 11 lestrum. Gert er ráð fyrir að lestrunum ljúki á laufskálahátíðinni. ${ }^{6}$

Í annan stað er pekkt textaröð sem gerir ráð fyrir lestri lögmálsins, p.e. Mósebókanna fimm, á premur árum, en um tvöfaldan lestur var par að ræða par sem að auki var lesið úr spámönnunum. Um var að ræða 153 til 167 skipti. Petta var svonefndur samfelldur lestur, á latínu lectio continua. Pessi lestraröð var notuð í Palestínu og er hún frá pví um miðja priðju öld e.Kr. Innan fræðanna er deilt um hvort samfelldur lestur hafi átt við um spámennina, en líklegt pykir að úr peim hafi verið lesnir valdir kaflar. 7 Í gyðinglegum handritum af ritum Gamla testamentisins er jafnan að finna merkingar sem sýna hvar lesari á að hefja lesturinn og enda, pessi merki nefnast petuba á hebresku sem pýðir „að opna“, auk pess sem sett er inn orðið setuma á hebresku, sem pýðir ,að loka“, par sem lesturinn á að enda. Í fornum handritum sem fundust í Kúmran (1947-1956), sem mörg hver eru frá pví nokkru fyrir Krists burð, er að finna vott um slíkar merkingar. ${ }^{8}$ Gera má ráð fyrir pví að í lestrum í samkunduhúsum hafi verið til einhvers konar textaraðir, en heimildir binda okkur við framangreindar raðir.

Í musterinu og samkunduhúsunum er gert ráð fyrir pví að lesið hafi verið upp úr Gamla testamentinu og í samkunduhúsum var lagt út af textanum eftir lestur. En til

Herwarth von Schade og Frieder Schulz (ritsti.), Perikopen: Gestalt und Wandel des gottesdienstlichen Bibelgebrauchs (Reibe Gottesdienst), Hamborg: Lutherisches Verlagshaus, 1978, bls. 10.

6 Laufskálahátiððin var pakkarhátíð sem haldin var að hausti í níu daga til pess að minnast 40 ára veru Ísraelsmanna í eyðimörkinni. Reistir voru litlir skálar úr lauftrjám við heimili og sýnagógur par sem fjölskyldur höfðust við á meðan á hátíðinni stóð. Sjá: Hans-Peter Mathys, „Gottesdienst“", Die Welt der Hebräischen Bibel: Umfeld — Inhalte — Grundthemen, ritstj. Walter Dietrich, Stuttgart: Kohlhammer, 2017, bls. 258-270, hér 263-265.

Gerhard Kunze, „Die Lesungen“, Leiturgia, 2. bindi, Kassel: Johannes Stauda-Verlag, 1955, bls. 88-179, hér 107.

8 Gottfried Reeg, „Perikopen“, bls. 1111; Sebastian Grätz, „Kanonbildung“, Die Welt der Hebräischen Bibel: Umfeld Inhalte - Grundthemen, ritstj. Walter Dietrich, Stuttgart: Kohlhammer, 2017, bls. 96-110, hér 104-108. Á íslensku er að finna aðgengilega umfjöllun um Dauðahafshandritin hjá: Hans Johan Sagrusten, Stóra púsluspilið: Leitin að elstu handritum Bibliunnar, pýð. Hreinn Hákonarson, Reykjavík: Skálholtsútgáfan, 2015, bls. 163-168. 
samkunduhússins er vísað hjá Flavíusi Jósefusi sagnaritara (37-100 e.Kr.) og einnig í Postulasögunni (15.21). En ekki er talið að í samkunduhúsum hafi verið um að ræða fyrirfram skilgreindar textaraðir sem bundnar voru tilteknum helgidögum. Menn telja að lesarinn hafi annaðhvort valið sjálfur pann texta sem lesinn var upp úr í lögmálinu og spámönnunum eða gengið inn í áframhaldandi lestur úr tilteknu riti. ${ }^{9}$ Dað hafi pví ekki verið um að ræða afmarkaðar og fyrirfram skilgreindar textaeiningar (períkópur). ${ }^{10}$ Í Lúkasarguðspjalli virðist t.d. gert ráð fyrir slíkum áframhaldandi lestri eða vali lesara úr tilteknu riti (Lúk 4.14-21). ${ }^{11}$ Fræðimenn telja pó ekki að frumsöfnuðurinn hafi tileinkað sér venju um ritningarlestur úr samkunduhúsum, heldur sé hér um að ræða samhliða próun. Rétt er pó að geta pess að margir fræðimenn telja að frumsöfnuðurinn í Jerúsalem hafi tekið mið af lestrum í musterinu í tengslum við sínar guðspjónustur, en guðspjónustuhefð pess safnaðar hafi ekki haft nein varanleg áhrif í frumsöfnuðinum og vægi hans hafi horfið eftir að söfnuðurinn fór frá Jerúsalem árið 66 og settist að í Pella og var eftir fall Jerúsalem árið 70 áhrifalaus með öllu. ${ }^{12}$ Af framangreindu má álykta að fyrst hvorki gyðingar né frumkirkjan hafi skilgreint hvaða rit tilheyrðu helgiritasafni sínu fyrr en á annarri og priðju öld, pá hafi textaraðirnar mótast samhliða peirri próun. ${ }^{13}$

Í ritum Nýja testamentisins er skírskotað til pessarar venju pegar talað er um að lesið sé upp úr ritningunni og í bréfum Páls er gert ráð fyrir pví að pau séu lesin á safnaðarsamkomum. Að minnsta kosti er nokkuð víst að bréf Nýja testamentisins voru lesin í heild eða að hluta í guðspjónustum og afmarkaður hluti eða kafli úr guðspjöllunum. ${ }^{14}$ Í rannsóknum á máltíðarsamkomum í hellenskum heimi er gert ráð fyrir að undir borðhaldi hafi menn lesið úr ritum, flutt erindi og rætt um innihald pess sem flutt var. Samkomur frumsafnaðarins í heimi hellenismans bera líka merki pessa. En раð skýrir hvers vegna í bréfum Nýja testamentisins er fjallað jöfnum höndum um guðfræði, siðferðileg álitamál, átök o.s.frv., jafnt og sálma sem og bænir. peir voru sungnir og pær beðnar á samkomum safnaðanna, sem jafnan voru tengdar málsverðum. Við pessi tilefni hafa hlutar úr guðspjöllunum verið lesnir og útskýrðir fyrir safnaðarfólki sem var að stórum hluta ólæst. Auk pessa bera rit Nýja testamentisins með sér sterkar kennslufræðilegar tilvísanir sem vísa til pess félagslega samhengis sem pessi bréf eru skrifuð inn í. Pau hafa greinilegt kennslufræðilegt markmið sem fræðslurit fyrir söfnuðinn. ${ }^{15}$

Dýski guðfræðingurinn Gerhard Kunze (1892-1954) skrifaði sígildar greinar um markmið, uppruna og próun textaraða kirkjunnar. Hann greinir á milli fimm sameiginlegra pátta sem lestrarnir höfðu í gyðingdómi, í frumsöfnuðinum og fornkirkjunni. ${ }^{16}$

Fyrst ber að nefna beitingu lestranna í guðspjónustunni sem kennslutækis, lestur ákveðinna texta og röð peirra hafði ákveðna merkingu samkvæmt samhengi peirra

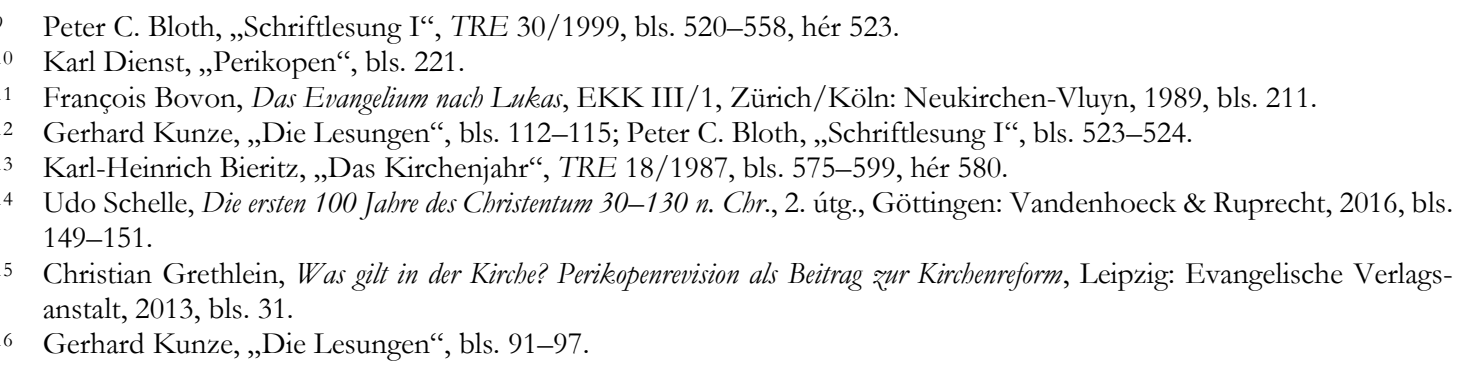


innbyrðis. Detta átti við um lestra í samkunduhúsum en líka innan kristinna safnaða par sem samhengi texta viðkomandi sunnudags við undangengna sunnudaga og staðsetning peirra innan kirkjuársins, sem var pegar í mótun, hafði einnig sitt hlutverk. Lestur texta úr ritum Gamla testamentisins eða bréfum og guðspjöllum gegndi hlutverki íhugunar, fræðslu og menntunar fyrir safnaðarfólk. Safnaðarfólk sem áheyrendur varð handgengið hjálpræðissögunni og tengslum hennar við sögu kirkjunnar og öðlaðist hæfni til að tengja textana eigin lífi. Pannig er komið á tengingu milli kirkjulegs og persónulegs lesturs. Hve mikilvæg pessi tengsl voru talin kemur vel fram í orðum kirkjuföðurins Kyrils í Jerúsalem (313-386): „Фað sem er ekki lesið í kirkjunni, áttu ekki að lesa heima."17 Miklu máli skipti hér hvaða rit urðu fyrir valinu, en innan kristninnar voru textar úr spámannaritunum mikilvægir fyrir túlkun á Kristsatburðinum, en í samkunduhúsum voru pað textar Mósebókanna.

Í annan stað fjallar Kunze um dulrænan skilning á lestrunum (b. Das magische Verständnis). Í heimi hellenismans áttu dulræn endurlausnartrúarbrögð vinsældum að fagna par sem hið hulda var í brennidepli og töfrar sem pví tengdust. Flutningur ritaðs orðs úr helgum ritum var talinn breyta lífi áheyrenda. Вað sem lesið var upphátt átti sér í raun og veru stað. Dessi hugmynd um heilagleika hins skrifaða orðs var mjög útbreidd í trúarbrögðum fornaldar og trúarbragðablöndu hellenismans. Óhætt er að segja að pessi skilningur sé enn til staðar í nútímanum. Segir Kunze að í pví sambandi nægi að benda á t.d. prentuð prófskírteini sem staðfesti að handhafi pess sé sá sem hann er. ${ }^{18}$

Í priðja lagi er um að ræða andlegan lestur og andlegan skilning. Hér hvílir áherslan ekki einungis á að lesið sé, heldur að andinn sé virkur í lestrinum. Hann lýkur upp fyrir söfnuðinum merkingu pess sem lesið er. Mikilvægi lestursins er bundið heilögum anda sem starfar í, með og undir orðinu. Virkni hans er bundin orðinu, pó að hann standi einnig utan pess. ${ }^{19}$ Lestur ritningarinnar í heimi kristninnar verður ekki losaður úr tengslum við söfnuðinn, staðsetningu innan guðspjónustunnar og ræktun trúarlífs einstaklingsins innan hans. ${ }^{20}$ Pýski guðfræðingurinn og trúarheimspekingurinn Ingolf U. Dalferth hefur í pessu samhengi áréttað að í kristindóminum er talið mikilvægt að greina skýrt á milli ritningarinnar sem orðs Guðs annars vegar og Biblíunnar sem bókar eða safns bóka hins vegar. Orð Guðs sé alltaf hið lifandi flutta orð. Orðið sem fagnaðarerindi mæti manninum ætíð sem persónulegt ávarp er snerti hann beint. Orð Guðs sé pví í raun Jesús Kristur og fagnaðarerindið um hann, en pað geti mætt manninum á tvo vegu, annars vegar sem lögmál og hins vegar sem fagnaðarerindi. Sami boðskapur geti virkað á báða vegu sem lögmál og fagnaðarerindi. Texti ritningarinnar feli í sér petta orð eða vísi til pess en verði ekki lagður að jöfnu við pað. Pess vegna er ritningin svo að segja ætíð túlkuð út frá Kristi og í samhengi við hann, eins og er svo vel dregið fram í frásögunni af Emmausförunum í Lúkasarguðspjalli (24.13-35). ${ }^{21}$ pessi munur á veruleika orðs Guðs sem ritningarinnar og Biblíunnar sem prentaðrar bókar varpar ljósi á pað hvers vegna kristnir söfnuðir geta

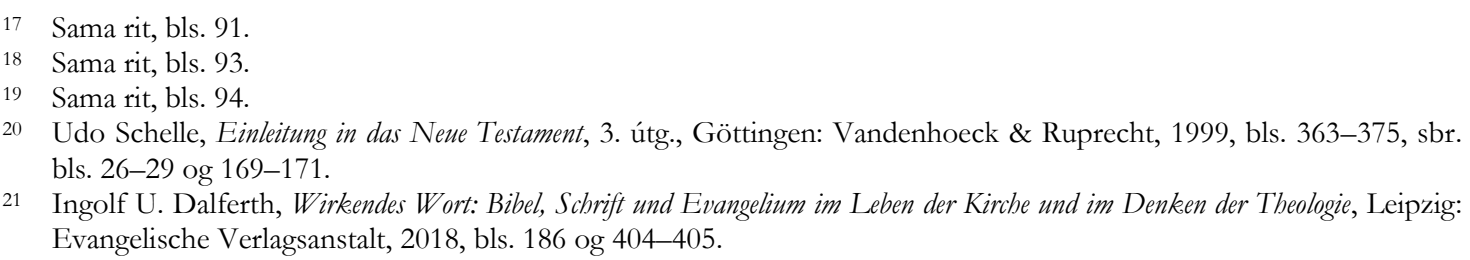

21 Ingolf U. Dalferth, Wirkendes Wort: Bibel, Schrift und Evangelium im Leben der Kirche und im Denken der Theologie, Leipzig: Evangelische Verlagsanstalt, 2018, bls. 186 og 404-405. 
vel prifist án pess að eiga Biblíuna sem bók og geti stuðst við minni textasöfn, en einnig að períkópur, eins og fyrsta textaröðin, nægja vegna pess að hér er um að ræða ákveðna texta úr ritningunni sem eru prungnir boðskap fagnaðarerindisins eða vísa sterkt til Krists. ${ }^{22}$

Í fjórða lagi hafði lestur upp úr ritum ritningarinnar mjög hagnýtt gildi. Í fornkirkjunni var vani að lesa við upphaf guðspjónustunnar. Markmiðið var að draga úr óróa innan guðspjónustunnar — vægi textanna jókst eftir pví sem leið á guðspjónustuna. ${ }^{23}$

Loks var í fimmta lagi um táknræna merkingu að ræða, par sem tengsl lestrar, inntak og útleggingar textans kallast á, en petta samband texta og táknrænnar merkingar hans er jafnan reifað í prédikuninni, hvernig hann knýr til Krists. ${ }^{24}$

Óhætt er að segja að pessir pættir séu að einhverju leyti enn í fullu gildi í guðspjónustu kristinnar kirkju.

\section{Fornkirkjan}

Til pess að skýra hina flóknu sögu um tildrög textaraðanna er aðferð Kunze auðvitað nærtæk. Hann setur saman greinargóða sögufléttu um hvernig pessi próun hafi verið í samræmi við rannsóknir sínar. Kunze gerir ráð fyrir pví að áhrif samkunduhúsanna á ritningarlestur í guðspjónustum frumsafnaðarins og fornkirkjunnar hafi verið takmörkuð af pví að guðfræðileg sjónarmið voru ekki einsleit. Annars vegar var lögð áhersla á lögmálið (fimmbókaritið), hins vegar Krist og spámannlegu hefðina innan frumsafnaðarins. Trúboðssöfnuðir í dreifingunni hafi lotið allt öðrum lögmálum en áttu við innan gyðingdóms. Peir mótuðust ekki af formfestu, heldur opnum huga og atorkusemi peirra sem tilheyrðu peim. Í endursögn er söguflétta Kunze eftirfarandi: Við erum stödd í Filippí árið 56 eftir fæðingu Krists. Söfnuður kristinna kemur reglulega saman á sunnudagsmorgnum. Forstöðumaður leiðir samkomuna en hann er einn af upprisuvottunum, ef til vill einn af peim sjötíu eða fimmhundruð bræðrum sem getið er um. ${ }^{25}$ Kunze kallar forstöðumanninn Theodas, en á samkomunni greinir Theodas frá Drottni, hvað hann gerði og sagði og svarar fyrirspurnum um efnið. Аð pví loknu eru sungnir sálmar og loks biður hann borðbæn áður er kærleiksmáltíðin hefst par sem menn neyta sameiginlega peirrar fæðu sem hver leggur til. Eftir máltíðina er farið með pakkarbæn og blessun áður en hver heldur til síns heima. Engin rit nota menn við pessar samkomur, andinn blæs peim í brjóst pað sem flytja ber og hvers skuli beðið. Auk pess eru sungnir sálmar. Aftur á móti á Theodas litla papírusrollu par sem finna má valda staði úr Gamla testamentinu. Um er að ræða staði sem tengjast sérstaklega spádómum um Krist og pjáningu hins réttláta. Hér er átt við texta úr Jesaja (Jes 42 og 53), Davíðssálmum (Slm 22; 27; 31; 41; 69) eða texta sem fjalla um komu Messíasar (Mal 2.17-3.6; 4.1-6; Jl 2 og 3; Sak 9-14). ${ }^{26}$ Út af pessum textum leggur forstöðumaðurinn og tengir Kristi, auk pess er hann meðá

\footnotetext{
Sama rit, bls. 402-403.

Gerhard Kunze, „Die Lesungen“, bls. 133-135.

Sama rit, bls. 97-102.

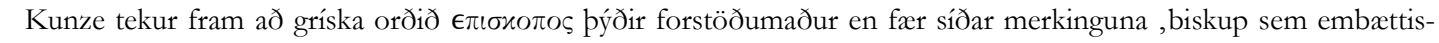
maður', eins og við pekkjum betur úr síðari tíma kirkjusögu. Sjá: Gerhard Kunze, „Die Lesungen“, bls. 119.

26 Sama rit, bls. 120. Um notkun lítilla papírusbóka má m.a. lesa hjá: Hans Johan Sagrusten, Stóra púsluspilid, bls. 19-20 og 63-65.
} 
litlum vaxtöflum skrifaðar nokkrar af dæmisögum og orðum Jesú sem hann hafði skrifað upp eftir frásögn annars manns til að halda henni lifandi. Dag einn kemur bréf til peirra frá Páli postula sem hann les í heild sinni á samkomunni og einnig næsta sunnudag til að fara betur yfir efni pess og skýra út pað sem Páll fjallar par um. Dag einn kemur til borgarinnar kristinn kaupmaður sem notar ferðir sínar til að fá að skrifa upp bréf Páls sem par er að finna og fær hann leyfi til pess með pví skilyrði að söfnuðurinn fái afrit af peim bréfum sem hann hefur meðferðis. Pannig safnast saman æ meira efni sem lesið er úr og lagt út af í guðspjónustum safnaðarins. ${ }^{27}$ Auk pess er farið að taka saman efnið sem til er um Jesú Krist og fram á sjónarsviðið koma guðspjöll sem innihalda mikið efni sem er frá Jesú komið, dæmisögur, ræður og atburði er tengjast lífi hans og umfram allt efni tengt píslarsögu hans. Detta efni hefur verið lesið og út af pví lagt í guðspjónustum og pað notað við fræðslu trúnema. ${ }^{28}$ pegar forstöðumaðurinn fellur síðan frá, líkt og aðrir frumvottar, verður enn nauðsynlegra að halda til haga pví efni sem til er og pað efni sem var til um Jesú Krist hefur einnig verið tekið saman í sérstök rit og 1 framhaldinu fara að mótast vissar venjur um hvaða textar eru lesnir við guðspjónustur og hátíðir safnaðarins. ${ }^{29}$ Á pennan hátt tekst Kunze að draga saman hvernig tildrög lestraraðanna tengjast ekki einungis mótun rita Nýja testamentisins, heldur dregur hann fram hlutverk peirra í mótun regluritasafnsins (kanonsins) og vægi peirra sem mælikvarða við hlið reglu trúarinnar og játninga. ${ }^{30}$

Snemma í sögu frumsafnaðarins er farið að tengja vissa texta við ákveðnar hátíðir. Detta á í fyrstu sérstaklega við um páskahátíð safnaðanna, en á priðju öld er hátíðin tiltölulega fastmótuð, sem og tíminn bæði fyrir og eftir hana. Litlu síðar, eða undir lok priðju aldar, koma jólin fram á sjónarsviðið sem sérstök hátíð, en rætur peirra liggja frekar í hellenskum menningarheimi. Páskarnir eru hins vegar kristin útfærsla á gyðinglegri trúarhátíð, sem nánar verður fjallað um síðar. Peir textar sem lesnir voru í tengslum við pessar hátíðir festust fljótlega í sessi og mynduðust ekki einungis textaraðir fyrir pær sjálfar, heldur líka fyrir pá sunnudaga og hátíðir sem tengdust peim, en um var að ræða föstutíma, jafnan 40 til 50 daga fyrir hátíðina, og svipaðan gleðitíma eftir hátíðina. Fram komu fastmótaðar textaraðir. Athyglisvert er að pessar hátíðir, og par með mótun kirkjuársins, fylgja náið byggingu Lúkasarguðspjalls og Postulasögunnar, pótt flestir textar kirkjuársins samkvæmt fyrstu textaröð séu úr Matteusarguðspjalli. Ástæða pess er að í Lúkasarguðspjalli er ekki einungis ýtarlegasta fæðingarfrásögnin (Lúk 2.1-35), heldur einnig frásagnir sem tengjast öllum helstu hátíðum kirkjuársins eins og píslarsögunni, páskum (Lúk 22-24), uppstigningardegi og hvítasunnu (Post 1-2). Í hinum guðspjöllunum er efninu raðað á nokkuð annan máta. Í Jóhannesarguðspjalli eru páskar, hvítasunna og himnaför Jesú bundin við einn dag (Jóh 20.17-23).

Sá sem tekur sér fyrir hendur að kanna hvernig ákveðnar „textaraðir“ urðu til í frumsöfnuðinum og fornkirkjunni verður að gera ráð fyrir mikilli fjölbreytni par sem slær saman ólíkum hugmyndum. Ef myndin er einfölduð má gera ráð fyrir pví að í

\footnotetext{
Nýjatestamentisfræðingurinn Udo Schelle bendir á að snemma hafi verið farið að safna saman bréfum Páls og par að verki hafi m.a. verið lærisveinar hans. Sjá: Udo Schelle, Einleitung in das Neue Testament, bls. 363-366.

Gerhard Kunze, „Die Lesungen“, bls. 126; Udo Schelle, Einleitung in das Neue Testament, bls. 202-212 og 367-369.

Gerhard Kunze, „Die Lesungen“, bls. 119-122.

Yfirlit yfir mótunarsögu Nýja testamentisins má m.a. sjá hjá: Udo Schelle, Einleitung in das Neue Testament, bls. 363-377.
} 
upphafi hafi andlegir spámenn og hrifningarmeistarar verið mótandi í guðspjónustunni. ${ }^{31}$ Eftir fráfall postula og frumvotta hefur pörfin fyrir meiri reglu og festu í helgihaldi orðið knýjandi. Раð átti einnig við um lestrana og túlkun peirra í guðspjónustunni. Í hellensku umhverfi mótaðist allt trúarlíf og öll trúariðkun af sterkri tilfinningu fyrir helgi og vitundinni um valdastiga innan trúfélaga og við helgisiði peirra. Kristnir söfnuðir voru pegar fram liðu stundir hér engin undantekning en peir tóku pennan skilning í arf. Pegar á annarri öld er farið að greina á milli djákna, presta og biskupa og skilja pá frá öðru safnaðarfólki. Í peirra hendur færast smám saman flestir pættir guðspjónustuhaldsins. Samhliða pessari próun verða til fastar textaraðir par sem tilteknir textar, sem bundnir eru við ákveðnar hátíðir, mynda heildstætt kerfi sem spannar allt kirkjuárið. Á priðju öld virðist að minnsta kosti orðin almenn venja í austurkirkjunni að lesa fjóra lestra. Annars vegar voru lesnir tveir lestrar úr Gamla testamentinu, p.e. söguritunum og ritum spámannanna, en vani var að nota Davíðssálma við daglegar bænagjörðir og pess vegna voru peir ekki teknir inn í textaröðina. Hins vegar voru lesnir tveir lestrar úr Nýja testamentinu, p.e. bréfunum og guðspjöllunum. ${ }^{32}$

Í fornkirkjunni voru við hlið sunnudagsguðspjónustunnar haldnar guðspjónustur sem höfðu sérstaka helgisiði og fasta lestra par sem fólk úr söfnuðinum eða aðrir lesarar lásu. Um er að ræða skírnarguðspjónustur, auk pess ber að geta um giftingarathafnir og jarðarfarir, en pá var algengt að fjölskyldumeðlimir læsu texta. Við bænastundir var auk pess lesið m.a. úr Davíðssálmum og ákveðnir textar úr bréfum Nýja testamentisins. ${ }^{33}$ Líkt og með Faðir vorið og blessunarformúlur var stuðst við texta Biblíunnar í guðspjónustum án pess að peir væru lesnir sérstaklega. Textarnir veittu orð, orðatiltæki, mál- og hugmyndaheim sem söfnuðurinn gat leitað í til að nálgast Guð í bæn, söng og prédikun. Textar ritningarinnar mótuðu pannig allt helgihaldið og helgisiði guðspjónustunnar. Dessi venja er allt til pessa dags mótandi fyrir guðspjónustuhald evangelísk-lúthersku kirkjunnar. Davíðssálmar eru notaðir sem bænatextar auk annarra, Faðir vorið hefur sinn fasta sess og í lok hverrar guðspjónustu er farið með blessun Arons. ${ }^{34}$ Leitað er til ritningarinnar varðandi innsetningarorðin við altarissakramentið og við skírnarathöfnina.

\section{Austurkirkjan}

Elsta textaröð (períkópa) sem vitað er um er frá 380 og er hún ættuð frá Antíokkíu. ${ }^{35}$ Í henni eru fjórir lestrar, p.e. úr lögmálinu og spámönnunum, bréfunum eða Postulasögunni og guðspjöllunum. ${ }^{36}$ Við hlið pessarar hefðar er önnur textaröð sem hefur

31 Gerhard Kunze, „Die Lesungen“, bls. 115-116. Nýjatestamentisfræðingurinn Jürgen Roloff gerir ráð fyrir meiri tengslum við samkunduhúsin og tengslum innan safnaðarlífs frumsafnaðarins en Kunze, en leggur pó áherslu á fjölbreytileikann. Sjá: Jürgen Roloff, „Der Gottesdienst im Urchristentum“, Handbuch der Liturgik: Liturgiewissenschaft in Theologie und Praxis der Kirche, ritstj. Hans-Christoph Schmidt-Lauber, Michael Meyer-Blanck, Karl-Heinrich Bieritz, 3. útg., Göttingen: Vandenhoeck \& Ruprecht, 2003, bls. 45-71, hér 56-58.

32 Herwarth von Schade og Frieder Schulz (ritstj.), Perikopen, bls. 14-15.

33 Christian Grethlein, Was gilt in der Kirche?, bls. 34.

34 Sjá nánar um hana: Sigurjón Árni Eyjólfsson, „Blessun Arons: Uppruni, notkun og áhrif“, Áhrif Lúthers: Siðaskipti, samfélag og menning i 500 ár, ritstj. Hjalti Hugason, Loftur Guttormsson og Margrét Eggertsdóttir, Reykjavík: Hið íslenska bókmenntafélag, 2017, bls. 445-468.

35 Gerhard Kunze, „Die Lesungen“", bls. 146-147.

36 Peter C. Bloth, „Schriftlesung I“, bls. 522, 524 (Const. Ap VIII, 5); Jürgen Roloff, „Gottesdienst im Urchristentum“, bls. $52-54$. 
svipaðar rætur, en hún er kennd við guðspjónustuna í Jerúsalem. Sú röð er alls óskyld peim venjum sem próuðust í frumsöfnuðinum í Jerúsalem. ${ }^{37}$ Hún náði mikilli útbreiðslu innan kirkjunnar á tímum Konstantínusar I keisara (306-337). Hann reisti margar kirkjur í Rómaveldi og í helgihaldi peirra var fylgt peirri venju musterisguðspjónustunnar að lesa tvo lestra úr Gamla testamentinu sem voru yfirfærðir á Nýja testamentið. Degar kvöldmáltíðarsakramentið var haft um hönd var lesið úr bréfunum og síðan guðspjöllunum. Á ýmsum minningardögum píslarvotta og helgra manna úr ritningunni voru lestrarnir prír og var pá bætt við einum úr Gamla testamentinu. Pessi hefð varð síðan ofan á í austurkirkjunni. ${ }^{38}$

Í sýrísku rétttrúnaðarkirkjunni er að finna fimm til sex lestra par sem prír eru úr Gamla testamentinu og prír úr Nýja testamentinu. Oftast voru pó í sýrísku kirkjunni — og pegar á fimmtu öld — prír lestrar, einn úr Gamla testamentinu og tveir úr Nýja testamentinu, og hefur pað haldist til pessa dags. Í armensku kirkjunni eru til textaraðir frá fimmtu öld en par er gert ráð fyrir að lesið sé úr spámönnunum, postulunum og guðspjöllunum. ${ }^{39}$ Um er að ræða lestraraðir og ekki mun alltaf hafa verið prédikað út frá peim.

\section{Vesturkirkjan}

Í vesturkirkjunni er fyrst á fimmtu öld að finna í Gallíu (Frakklandi) tilhneigingu til útgáfu á textaröðum fyrir allt kirkjuárið. Um er að ræða tvo texta fyrir hvern sunnudag, annan úr Gamla testamentinu eða bréfunum og hinn úr einu guðspjallanna. ${ }^{40}$ Á sjöundu öld koma fram í Róm fastar textaraðir og líklegt pykir að textaröðin yfir guðspjöllin par eigi rætur að rekja til textaraða úr guðspjöllunum sem Gregor mikli páfi setti saman um 645 til að prédika út frá. ${ }^{41}$ Innan kirkjulegrar hefðar eru pessar textaraðir að hluta til raktar til samantektar sem eignuð er Híerónýmusi kirkjuföður (347-420). ${ }^{42}$ Pessi hefð var bundin við Róm og nánasta umhverfi, en önnur hefð er bundin við norðurhluta Ítalíu, Gallíu, Spán og Bretland. Úr peirri hefð hafa verið teknir inn í fyrstu textaröðina pistlarnir og textar úr Gamla testamentinu. Sú textaröð er að öllum líkindum að stofni til frá sjöttu öld. Ef pessi flókna saga er einfölduð má segja að á áttundu öld, pegar Karl mikli (748-814) lét endurskipuleggja guðspjónustuhaldið og fól pað Alkuin (735-804), hirðguðfræðingi sínum, voru pessar tvær hefðir — gallíska og rómverska textaröðin — settar saman í eina. Guðspjallstextarnir fylgja rómversku hefðinni en pistlarnir eru teknir upp úr hinni gallísku. ${ }^{43}$ Ekki var fengist um pá spennu sem er á milli pistla og guðspjallstexta. Lestrarnir voru með pessum aðgerðum samrýmdir fyrir guðspjónustuhald kirkjunnar. Prestar voru auk pess skyldugir til að lesa úr guðsorðabókum eða hómilíum sem innihéldu útleggingar á guðspjallstexta tiltekins sunnudags. ${ }^{44}$ Allar miðaldir var engin krafa gerð til presta um

\footnotetext{
37 Í uppreisn gyðinga gegn Rómverjum flúði frumsöfnuðurinn Jerúsalem og settist að í Pella eins og fyrr er getið. Eftir fall Jerúsalem árið 70 missti gyðing-kristni vægi sitt og áhrif heiðin-kristinna urðu mótandi. Sá söfnuður sem mótaðist í Jerúsalem eftir fall borgarinnar árið 70 bar pess greinileg merki að tengslin voru ekki lengur til staðar. Sjá: Gerhard Kunze, „Die Lesungen“, bls. 135-136 og 141-142.

38 Peter C. Bloth, „Schriftlesung I“", bls. 526; Karl Dienst, „Perikopen“, bls. 222.

39 Herwarth von Schade og Frieder Schulz (ritsti.), Perikopen, bls. 15; Gerhard Kunze, „Die Lesungen“, bls. 147-148.

40 Peter C. Bloth, ,Schriftlesung I“, bls. 527.

41 Karl Dienst, „Perikopen“, bls. 222.

42 Herwarth von Schade og Frieder Schulz (ritstj.), Perikopen, bls. 18.

43 Gerhard Kunze, „Die Lesungen“, bls. 150.

44 Isnard W. Frank, „Predigt VI“, TRE 27/1997, bls. 248-262, hér 252.
} 
að peir flyttu sjálfstæðar prédikanir. Í textaröð pistlanna er einnig að finna texta úr Gamla testamentinu (lexíur), en aðallega er um að ræða texta úr ritum spámannanna. Pessi textaröð er kölluð fornkirkjulega textaröðin og er nefnd m.a. í Handbók íslensku kirkjunnar fyrsta textaröðin. ${ }^{45}$ Allar miðaldir var hún lesin á latínu í kirkjum og hafði fyrir pá sem lítt skildu pað mál innan guðspjónustunnar oft magiskan eða dulrænan töfrablæ. Meirihluti safnaðarins hefur lítt skilið pað sem lesið var og mennta- eða uppeldislegt vægi lestranna um aldir pví takmarkað. Á miðöldum er ekki finna neinar heimildir um einhverja endurskoðun pessarar raðar. Баð var einungis fengist lítillega við helgidagaskrá dýrlinga og texta peim tengda. Miðaldakirkjan var fyrst og fremst kirkja sakramentanna og var orðið og útlegging pess meira eða minna í höndum förumunkareglna. Prédikunin var pannig séð ekki fastur liður í guðspjónustunni pó að hún hefði par sinn stað. ${ }^{46}$

Ef petta er tekið saman er ljóst að í frumsöfnuðinum var fastur liður að lesið væri úr ritningunni, aðallega textum úr spámannahefðinni, bréfum postula og greint frá orði og verkum Jesú. Lestrarnir gátu bæði verið samfelldir (1. lectio continua) eða valdir kaflar. Bæði í austur- og vesturkirkjunni er á fimmtu öld að finna textaraðir sem spanna allt kirkjuárið. Karl mikli kom skipulagi á guðspjónustuhald í ríki sínu og pá er fornkirkjulega textaröðin gerð að lestraröð fyrir allt ríki hans. Par eru settar saman tvær sjálfstæðar raðir sem eiga rætur að rekja allt til fjórðu og fimmtu aldar, önnur innihélt pistlana og er úr gallískri hefð, en hin guðspjallstextana og er úr rómverskri arfleifð. Hún hélst fram að siðbót og var yfirtekin af Lúther og evangelísk-lúthersku kirkjunni, en dagar heilagra og dýrlinga voru teknir til endurskoðunar.

\section{Marteinn Lúther og textaraðirnar}

Lúther ætlaði sér aldrei að stofna kirkjudeild eða nýja kirkju. Hann vildi einungis tryggja að pað sem flutt var í kirkjunni væri í samræmi við fagnaðarerindið og taldi að hafna bæri peim atriðum sem stönguðust á við pað. ${ }^{47}$ Hann tekur djúpt 1 árinni og heldur pví fram að ef ekki sé prédikað út frá guðspjalli eigi ekki heldur að syngja pað, betra sé að menn lesi pað pá. Lestur pess einn og sér sé pó lítt betri, en pað var sú hefð sem hafði verið ríkjandi í klaustrum og stofnunum. ${ }^{48}$

Lúther gagnrýndi pá einhliða áherslu á siðferðilegar áminningar og hvatningu til réttrar breytni sem kom fram í textum pistlanna. Hann áleit að greinilegt væri að pann sem hefði tekið pá saman hefði skort bæði menntun og trú. Allt annað væri uppi á teningnum um valið á textum úr guðspjöllunum. Í riti sínu Formula Missae frá 1523 um guðspjónustuna vill Lúther að textaraðirnar verði endurskoðaðar og aðrir textar úr bréfunum valdir fyrir pistlana. ${ }^{49}$ Par segir m.a.: „Lesturinn úr pistlum og guðspjöllum var og er einnig gagnlegur, hefðu menn ekki gert pau mistök að lesa textana á

\footnotetext{
Handbók islensku kirkjunnar, Reykjavík: Kirkjuráð, 1981.

Christian Grethlein, Was gilt in der Kirche?, bls. 35.

7 Luthers Werke: Kritische Gesamtausgabe [Schriften], 73 bindi, Weimar: Hermann Böhlaus Nachfolger, 1883-2009 (framvegis skammstafað WA), 11, bls. 74.

4 WA 12, bls. 35-36.

49 WA 12, bls. 209-210 (sbr. einnig Dr. Martin Luthers sämmtliche Scbriften, ritstj. Johann Georg Walch, 23 bindi, St. Louis: Concordia, 1881-1910 (framvegis skammstafað Walch), X, bls. 2239). Sjá einnig: WA 19, bls. 80 (sbr. Walch X, bls. 233-234).
} 
tungumáli sem fólkið skildi ekki.“50 Og stuttu síðar ritar hann: „Annars eru sjaldan lesnir kaflar úr bréfum Páls par sem fjallað er um trúna, aðallega eru par textar sem fjalla um siðferðilega hluti eða hvatningartextar.“51 Ástæðuna fyrir pessu textavali telur Lúther vera pá að sá sem skipulagði pistlana hafi verið „áberandi illa að sér og hjátrúarfullur". 52 Áhersla í framsetningu Lúthers hvílir nokkuð á kennslufræðilegu vægi fornkirkjulegu textaraðarinnar.

Prátt fyrir bessa gagnrýni vill hann ekki breyta textaröðinni eins og kemur vel fram í greinargerð hans um guðspjónustuna frá 1526, Dýsk messa (p. Deutsche Messe). Par kemur fram að Lúther vill auka vægi textaraðarinnar með pví að prédika einnig út af öðrum kjarnatextum kristninnar. Hann segir: „Dessari fræðslu get ég ekki skipað betur eða verr en hún var sett fram við upphaf kristninnar og hefur haldist síðan, pað er að segja í premur liðum, boðorðunum tíu, trúarjátningunni og Faðir vor. Í pessu prennu stendur nánast allt, stutt og laggott, sem nauðsynlegt er fyrir kristinn mann að vita. " ${ }^{3}$ Lúther kveður skýrt á um vægi pess að leggja út af pessum atriðum sem hann sjálfur gerir í svonefndum katekismus-prédikunum sínum. Varðandi pær segir hann að menn haldi ,að ekki sé annað að gera en að hlusta um stund, en dettur ekki í hug að læra eða halda neitt af pví sem peir hafa heyrt. Pannig heyrir margur maðurinn prédikanir í prjú, fjögur ár, en lærir pó ekki svo mikið að hann geti svarað út úr einum lið trúarjátningarinnar (pess verð ég daglega var). Nóg er skrifað í bókum, víst er um pað, en ekki hefur pví öllu verið komið inn í hjörtun. "54 Hann hvetur til pess að nemendur séu látnir lesa úr ritningunni kvölds og morgna. Рað væri í samræmi við fornkirkjulegu textaröðina, en par að auki væri lesið skipulega úr Gamla og Nýja testamentinu við morgun- og kvöldguðspjónustur. Lúther setur fram tillögu að eftirfarandi skipan mála:

\footnotetext{
Á helgidögum eða sunnudögum höldum við óbreyttum venjulegum pistlum og guðspjöllum og prenns konar prédikunum. Snemma dags, um kl. 5 eða 6 , eru sungnir einhverjir sálmar eins og við óttusöng. Dví næst er pistill dagsins prédikaður, fyrst og fremst vegna pjónustufólksins, svo að fyrir pví sé séð og pað heyri Guðs orð, ef pað getur ekki verið viðstatt hinar prédikanirnar. [...] Við messuna um kl. 8 eða 9 er prédikað út frá guðspjallinu samkvæmt kirkjuárinu. Síðdegis við kvöldsönginn er Gamla testamentið prédikað áframhaldandi [...]. Ástæðan fyrir pví að við höldum skiptingu pistla og guðspjalla eftir kirkjuárinu, eins og siður hefur verið, er sú að við höfum ekkert við hana að athuga. [...] Við álítum að leikmaðurinn fái næga prédikun og fræðslu í pessu. ${ }^{55}$
}

Auk pessa leggur Lúther til að á mánudögum og priðjudögum sé lesið upp úr katekismanum (kverlærdómnum) eða boðorðunum, trúarjátningunni og Faðir vorinu og lagt út af pessu. Á miðvikudögum sé tilvalið að lesa úr Matteusarguðspjalli en úr Jóhannesarguðspjalli á laugardögum, sem eru hentug til fræðslu almennings. Aftur á móti á að lesa við morgunguðspjónustur á fimmtudögum og föstudögum úr pistlum postulanna og bví sem eftir er af Nýja testamentinu. Lúther setur hér fram kerfi um hvernig eigi að lesa úr ritningunni hvern dag vikunnar og telur að nauðsynlegt sé að

\footnotetext{
50 Marteinn Lúther, Helgisiðir og kvöldmáltí í: Marteinn Lúther: Úrval rita 1, 1517-1523, pýð. Gunnar Kristjánsson, Reykjavík: Nefnd um fimm alda minningu siðbótarinnar og Skálholtsútgáfan, 2017, bls. 361-379, hér 363.

51 Sama rit, bls. 365 .

Sama rit, bls. 365

3 Marteinn Lúther, Dj́sk messa og skipan guðspjónustu, í: Marteinn Lúther: Úrval rita 2, 1524-1545, pýð. Gunnar Kristjánsson, Reykjavík: Nefnd um fimm alda minningu siðbótarinnar og Skálholtsútgáfan, 2018, bls. 99-118, hér 103.

54 Sama rit, bls. 105.

55 Sama rit, bls. 106.
} 
nemendur lesi hvern dag vikunnar við slíkar stundir úr ritningunni og syngi sálma á latínu eins og tíðkast hafði til pessa við óttusöng. ${ }^{56}$

Vegna peirra stúdenta sem voru við nám í háskólanum í Wittenberg vildi Lúther meðal annars ekki setja inn nýjar textaraðir. ${ }^{57}$ Hann vildi fara hér hægt í sakirnar til að skerða ekki pað uppeldisgildi sem festa í kirkjuárinu hafði fyrir safnaðarfólk. Lúther hélt pví fast við guðspjallatextana, en breytti pó nokkuð með tíð og tíma valinu á textum í pistlunum. ${ }^{58}$ Hann valdi pá með hliðsjón af guðspjallstextanum sem var í huga hans pungamiðja lestranna. Innan textaraðanna mynda peir helming pess efnis ritningarinnar sem lesið er í guðspjónustunni. Pegar efni peirra er skoðað kemur í ljós að peir veita yfirgripsmikla innsýn í hjálpræðissöguna. ${ }^{59}$ Mælikvarðinn sem Lúther studdist við í mati sínu á peim var boðunargildið, pess vegna vildi hann að lagt væri út af peim í prédikuninni. ${ }^{60}$ Markmið prédikunarinnar var að fræða og hugga manninn í samhljóðan við guðspjallið. 61

Lestri parf að fylgja útlegging að mati Lúthers. Fyrir guðspjónustur á sunnudögum vildi Lúther að prédikað væri út frá fyrstu textaröð eða fornkirkjulegu röðinni annaðhvort út frá pistli eða guðspjalli. Hann var vissulega með sínar athugasemdir gagnvart pistlaröðinni, sem honum fannst valin og sett saman með of prönga siðferðilega mælikvarða í huga. Í peim væri ekki tekið nægilegt tillit til pess sem Páll segir um trúna í bréfum sínum. Hann kom ekki með neinar tillögur um breytingar nema varðandi helgidaga sem tileinkaðir voru dýrlingum en helgidagatal hreinsaði hann af öllum dýrlingum og helgum mönnum sem ekki var getið um í Biblíunni. Hann áleit pó leyfilegt að nýta sér aðra texta og efni til prédikana og útlegginga og var ekki fráhverfur samfelldum lestri (1. lectio continua) tiltekinna rita og útleggingu á peim. Lúther kom að útgáfu tveggja postilla með prédikunum sínum og í annarri peirra er lagt út af fyrstu textaröðinni, annars vegar textum guðspjallanna og hins vegar pistlanna. Auk pess prédikaði hann út frá samfelldum lestri á stórum hluta Matteusar- og Jóhannesarguðspjalls, auk rita Gamla testamentisins eins og Sálmum Davíðs og Spádómsbók Jesaja, svo að eitthvað sé nefnt. Pær tillögur sem Lúther setti fram vildi hann ekki að yrðu skoðaðar sem óhagganlegt lögmál, heldur að pær bæri að nýta í samræmi við hið kristna frelsi. ${ }^{62}$ Markmið guðspjónustunnar og textaraðarinnar er að lofa Guð og hugga hrelldar sálir, en sá páttur er síðar tekinn upp í Ágsborgarjátningunni. Pað á ekki að breyta breytinganna vegna, heldur vegna pess sem parf til að pjóna fagnaðarerindinu.

Sem munkur og prestur pekkti Lúther vel handbækur kirkjunnar og pær textaraðir sem voru notaðar í guðspjónustunni. Dýski guðfræðingurinn Gerhard Kunze hefur bent á hve mikla alúð Lúther lagði við lesturinn á textum ritningarinnar í guðspjónustunni. ${ }^{63}$ pegar Lúther endurskoðaði messuna varði hann miklum tíma í að tónsetja lestrana. Hann vildi að hver lestur væri sunginn í tiltekinni tónhæð. Pistlana

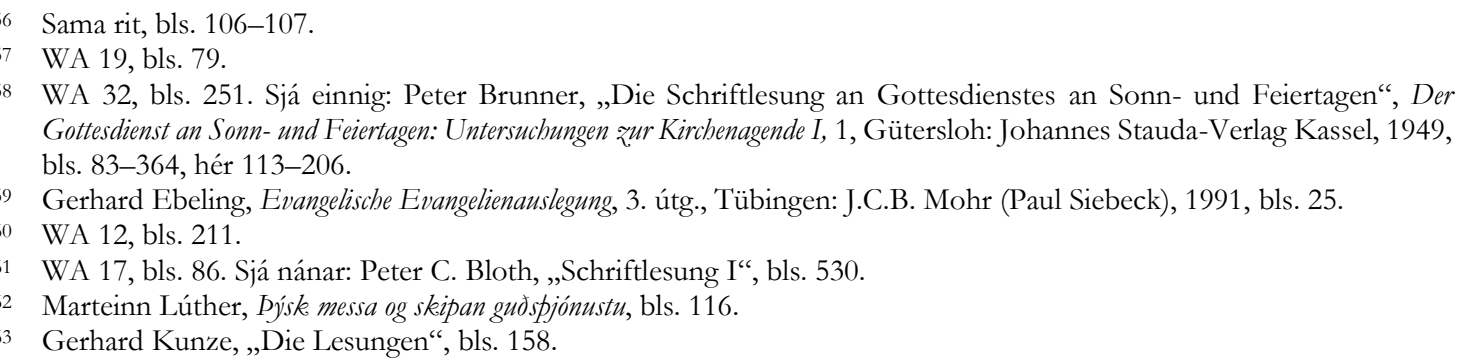


ætti að syngja út frá sjötta tóni, en hins vegar vildi hann að guðspjöllin væru tónuð frá peim áttunda. Pessa áherslu og vandvirkni hjá Lúther má rekja til peirrar sannfæringar að í fluttu orði ritningarinnar stigi Kristur fram og tali beint til safnaðarins. Og pó að presturinn sé hluti af söfnuðinum, pá hljómar rödd Krists í hans rödd. Kunze segir að með Lúther hafi komið fram alveg ný áhersla „sem í nærri púsund ár hafði lítið verið hugað að: Раð átti að virða boðunargildi ritningartextanna.“64 Uppruni textaraðanna á fimmtu og sjöttu öld er auk pess sá að peir eru upphaflega teknir saman til að vera prédikunartextar. En pessi almenna prédikunarhefð deyr út á miðöldum, en textarnir eru lesnir á latínu við hverja guðspjónustu. Eins og gefur að skilja skildu peir sem ekki voru vel að sér í henni lítt pað sem lesið var, en pessi vani hafði pau áhrif að fyrsta textaröðin hélst óbreytt, en pær breytingar sem voru gerðar síðar sneru að textum á dögum sem tileinkaðir voru hinum mörgu dýrlingum.

Detta breyttist hins vegar algjörlega með Lúther og siðbótinni. Guðspjónustan var flutt á móðurmálinu og í prédikuninni voru lestrarnir útlagðir. Lúther hélt sig við textaröðina pegar hann prédikaði í guðspjónustunni á sunnudögum, um morguninn lagði hann út af guðspjalli en síðdegis út af pistli. Aftur á móti pegar hann prédikaði í miðri viku, p.e. á miðvikudögum og laugardögum, lagði hann út af heilu ritunum og viðhélt par hefðinni um samfelldan lestur ritningarinnar (1. lectio continua). ${ }^{65}$ Lúther hnýtir pannig saman lestrana og prédikunina að annað er óhugsandi án hins. ${ }^{66}$

раð sem hér hefur fram komið má pá draga saman pannig að Lúther (a) styðst eindregið við textaröð fornkirkjunnar, hann (b) víkur einungis frá henni í undantekningartilvikum og velur sér annan texta, (c) fylgir textaröðinni að fullu í guðspjónustum á helgidögum og loks (d) leggur hann aðallega út af guðspjallatextunum. ${ }^{67}$

\section{Aðrir siðbótarfrömuðir}

Ulrich Zwingli (1484-1531) og Jóhann Kalvín (1509-1564) taka aðra afstöðu til fyrstu textaraðarinnar en Lúther. Ástæða pess er að Zwingli er undir áhrifum af nokkuð annarri hefð par sem guðspjónusta prédikunarinnar situr í fyrirrúmi í siðbótarstarfinu, en hún var mótandi í Suður-Dýskalandi og Sviss og átti rætur að rekja allt aftur til níundu og tíundu aldar. Með henni var komið til móts við parfir safnaðarins fyrir prédikanir á móðurmálinu. Pessi gerð guðspjónustu kallaðist Pronaus (fr. prône; 1 . preaconium = að boða). Hér var um að ræða guðspjónustu sem tók fyrst og fremst mið af prédikuninni eða boðuninni. Í tengslum við hana próaðist sérstakt guðspjónustuform par sem kvöldmáltíðarsakramentið var ekki lengur hluti af helgihaldinu. ${ }^{68}$ Boðið var upp á altarisgöngu eftir guðspjónustur eða á milli tveggja slíkra. Á tólftu öld jukust áhrif prédikunarreglna fransiskana og dóminíkana og pá var jafnvel gengið svo langt að reisa sérstakar kirkjur fyrir prédikunarguðspjónustur. Pessi hefð hafði varanleg áhrif á svæðum par sem siðbótarstarf Zwinglis fór fram og síðar

\footnotetext{
Sama rit, bls. 161.

65 Martin Brecht, Die Erhaltung der Kirche, 1532-1546, Martin Luther 3, Stuttgart: Calwer Verlag, 1987, bls. 248; Albrecht Beutel, „Predigt VIII“, TRE 27/1997, bls. 296-311, hér 297.

66 Um mat Lúthers á einstökum textum fyrstu textaraðarinnar, sjá: Peter Brunner, „Die Schriftlesung an Gottesdienstes an Sonn- und Feiertagen“, bls. 113-206.

67 Gerhard Ebeling, Evangelische Evangelienauslegung, bls. 21-22.

68 Eberhard Winkler, „Predigtgottesdienst“, Handbuch der Liturgik: Liturgiewissenschaft in Theologie und Praxis der Kirche, ritstj. Hans-Christoph Schmidt-Lauber, Michael Meyer-Blanck, Karl-Heinrich Bieritz, 3. útg., Göttingen: Vandenhooek \& Ruprecht, 2003, bls. 247-267, hér 251.
} 
Kalvíns. ${ }^{69}$ Í pessum guðspjónustum var lögð meiri áhersla á samfelldan lestur en fyrstu textaröð. Lúther pekkti vissulega til pessarar hefðar og byggir á henni í umfjöllun sinni um prédikunarguðspjónustur sem hann vildi að haldnar væru á virkum dögum, en hann bindur pær að vísu við byggingu tíðasöngsins. Hann sló með öðrum orðum saman óttusöng fyrri (1. matutinum) og óttusöng efri (1. laudes) í einn tíðasöng sem hann nefndi morgunsöng (p. Mette) og miðaftantíð (1. vesper)..$^{70}$

Zwingli vildi aftur á móti byggja á prédikunarhefðinni að öllu leyti. Í samræmi við pað hafnaði hann fornkirkjulegu textaröðinni sem honum fannst vera undir of miklum áhrifum frá Róm. Pessi afstaða kemur skýrt fram í peirri kirkjuordinansíu (fyrirmælum um skipan kirkjumála) sem gefin var út í Zürich 1525 og 1535. Petta hafði pær afleiðingar að pað losnaði um hin nánu tengsl sem verið höfðu á milli ritningarlestursins og kirkjuársins, sem einmitt einkenna fyrstu textaröðina. Zwingli lagði mesta áherslu á fræðsluhlutverk boðunarinnar sem tengdist samfelldum lestri á ritum ritningarinnar og útleggingu á efni hennar í prédikuninni. Dessi afstaða hans endurspeglast vel í skilningi hans á vægi og stöðu altarissakramentisins sem hann túlkar fyrst og fremst sem minningarathöfn. ${ }^{71}$

Jóhann Kalvín hafnaði líka fyrstu textaröðinni og nýtti sér hefð prédikunarguðspjónustunnar, hugmyndina um samfelldan ritningarlestur. Аð mati hans var pað pó ekki eingöngu á valdi prestsins og safnaðarráðsins að ákveða hvaða texti skyldi lesinn í endurbættu (reformertu) kirkjunni. Í kirkjuordinansíu í Kurpfalz frá 1563 er kveðið á um að tilsjónarmaður eða biskup hverrar kirkju skuli ákveða hvaða texta skuli lesa í guðspjónustum og út frá hvaða textum prédikað. ${ }^{72}$ Í staðinn fyrir að halla sér að hefðinni, eins og ítrekað er m.a. í Ágsborgarjátningunni frá 1530 fyrir lúthersku kirkjudeildina, færist úrskurðarvaldið um val á textum í kirkjudeild kalvínista í hendur embættismönnum kirkjustjórnarinnar.

Degar fram liðu stundir hafði pessi próun pær afleiðingar að afstaðan til ritningarlesturs guðspjónustunnar greindi að kirkjudeildirnar tvær og gat beinlínis sagt til um hvorri kirkjudeildinni einstaklingar tilheyrðu. Pannig varð fyrsta textaröðin að samnefnara fyrir evangelísk-lúthersku kirkjuna en samfelldur lestur fyrir kalvínsku kirkjuna. ${ }^{73}$

\section{Niðurstöður}

Hugmyndir Lúthers um guðspjónustuhald á miðvikudögum og laugardögum, par sem byggt væri á samfelldum lestri, reyndust lítt framkvæmanlegar til lengri tíma. Guðspjónustuhald á sunnudögum og öðrum föstum helgidögum kirkjuársins varð ofan á, en par varð fyrsta textaröðin mótandi. Í kjölfar upplýsingarinnar og fyrir áhrif píetismans urðu pær ræddir æ háværari sem fóru fram á að textaröðin yrði endur-

9 Sama rit, bls. 253.

70 Einar Sigurbjörnsson, Embattisgörd: Guðfraði pjónustunnar i sögu og samtíð, Reykjavík: Skálholtsútgáfan, 1996, bls. 150_ 151.

71 Christian Grethlein, Was gilt in der Kirche?, bls. 38; Sigurjón Árni Eyjólfsson, Gudfradi Marteins Lúthers: Í ljósi túlkunar hans á Jóhannesarguðspjalli 1535-1540, Reykjavík: Hið íslenska bókmenntafélag, 2000, bls. 300-302.

72 Peter C. Bloth, ,Schriftlesung I“, bls. 531.

73 Sama rit, bls. 553. 
skoðuð og að innleiða bæri samfelldan lestur og leggja meiri áherslu á pemaprédikanir. ${ }^{74}$ Dessar kröfur eru bein afleiðing af aukinni útbreiðslu Biblíunnar og biblíupekkingu almennings sem var miðlæg í trúarhugsun fulltrúa píetismans. Í nokkrum endurskoðunum textaraðarinnar, t.d. í Dýskalandi og á Norðurlöndum, og viðbótum við hana er reynt að koma til móts við pessar kröfur. Full pörf er á að gera grein fyrir peirri sögu sérstaklega, ekki síst áhrifum hennar á Íslandi, en pað verður pó ekki gert að pessu sinni. ${ }^{75}$

Að framangreindu er ljóst að textaraðir fornkirkjunnar próuðust samhliða helgiritasafni kristninnar. Áberandi er í peirri próun að textarnir sem lentu inni í lestrunum purftu að fullnægja tilteknum skilyrðum og er par helst að nefna að peir urðu að vera margræðir og opnir fyrir túlkunum. Pessir textar urðu fyrir valinu af pví að peir eru hlaðnir fagnaðarerindinu og margbreytileika pess, en pað á alls ekki við um alla texta ritningarinnar. Dessi margræðni textans kemur hins vegar í veg fyrir einhliða siðferðistúlkun. Í annan stað raðast peir saman til að mynda skipulega heild kringum meginhátíðir kristninnar, páska, jól og síðar prenningarhátíðina. Í mótun kirkjuársins reyndist ekki unnt að viðhalda samfelldum línulegum lestri, heldur purfti að tengja saman texta til pess að peir mynduðu eina heild. Í sögu kirkjunnar próuðust tvær hefðir, að lesa texta textaraðarinnar á sunnudögum og leggja út af honum, en samfelldur lestur á öðrum textum utan raðarinnar voru bundnir við aðra daga vikunnar. Í kjölfar siðbótarinnar klofnaði pessi hefð. Í lútherskum kirkjum er stuðst við textaröð fornkirkjunnar en í kalvínsku kirkjunni og Zwingli-hefðinni er stuðst við lectio continua eða valda texta.

Pegar saga fyrstu textaraðarinnar á Íslandi er skoðuð liggur nærri að fullyrða að hún hafi verið mótandi allt frá kristnitöku. ${ }^{76}$ Aðeins hefur verið bætt við textaröðum og einum og einum lestri eða lexíu úr Gamla testamentinu í Handbókinni 1981. Petta á sér pær skýringar að eftir seinni heimsstyrjöld varð pað sjónarmið ofan á að nauðsynlegt væri að varpa ljósi á rætur kristninnar í arfleifð Gamla testamentisins og sameiginlegrar hefðar gyðingdóms og kristni. Áberandi er í endurskoðunum textaraðarinnar hversu mikil alúð hefur verið lögð við að finna texta í Gamla testamentinu sem eru í samhljóman við pistil og guðspjall.

Gera verður skýran greinarmun á textaröðinni og almennum biblíulestri. Lestur í guðspjónustu hefur ekki pað markmið að auka biblíupekkingu fólks, heldur að miðla fagnaðarerindinu.

\footnotetext{
Sama rit, bls. 540 .

75 Pessi flókna saga er vel rakin hjá: Christian Grethlein, W as gilt in der Kirche?, bls. 41-56. Sjá einnig: Herwarth von Schade og Frieder Schulz (ritstj.), Perikopen, bls. 34-72; Karl-Heinrich Bieritz, „Es wechseln die Zeiten: Perikopenreformen seit 1896 und ihr hermeneutischen Horizont“, Auf den Weg zur Perikopenrevision: Dokumentation einer wissenschaftlichen Fachtagung, Hannover: Kirchenamt EKD, UEK og VELKD, 2010, bls. 115-133.

76 Prédikunarsöfn taka t.d. gjarnan mið af henni og innihalda að stórum hluta prédikanir út frá textum fyrstu raðarinnar, svo að ekki sé minnst á Vísnabók Guðbrands sem inniheldur vísur og ljóð fyrir texta kirkjuársins samkvæmt fyrstu textaröðinni. Í Vísnabókinni er fyrst greint frá efni guðspjallsins og síðar er í nokkrum erindum að finna útleggingu eða heimfærslu. Einnig má par sjá ýtarlega umfjöllun um helstu hátíðir kirkjunnar og atriði sem tengjast kristilegu líferni. Ef Íslensk hómilíubók er skoðuð blasir hið sama við. Íslenskar postillur fylgja fyrstu textaröðinni, hinni fornkirkjulegu röð, bæði í guðspjallstextunum og pistlunum.
} 